\title{
Short Communication: Intraspecific genetic diversity and population subdivision of rabbitfish (Siganidae: Siganus canaliculatus) in urbanized reefs of Jakarta Bay, Indonesia
}

\author{
HAWIS MADDUPPA`, MUTIARA KRISTINA MARGARETHA, ADITYA BRAMANDITO, TRI PRARTONO, \\ BEGINER SUBHAN, DONDY ARAFAT, NURLITA PUTRI ANGGRAINI \\ Department of Marine Science and Technology, Faculty of Fisheries and Marine Science, Institut Pertanian Bogor. J1. Darmaga Raya, Bogor 16680, \\ West Java, Indonesia. Tel./fax.: +62-251-8623644, `email: hawis@apps.ipb.ac.id
}

Manuscript received: 15 June 2019. Revision accepted: 8 August 2019.

\begin{abstract}
Madduppa H, Margaretha MK, Bramandito A, Prartono T, Subhan B, Arafat D, Anggraini NP. 2019. Short Communication: Intraspecific genetic diversity and population subdivision of rabbitfish (Siganidae: Siganus canaliculatus) in urbanized reefs of Jakarta Bay, Indonesia. Biodiversitas 20: 2897-2902. Indonesian coral reefs and seagrass are heavily influenced by human activities through pollution and habitat loss, and sea-level rise or the increase of ocean temperature due to the global change. In the Jakarta Bay and Seribu Islands, marine communities have been impacted by an increase in eutrophication and sedimentation levels. As a result, these habitats became degraded and could affect their associated organisms such as rabbitfish. Genetic diversity and population structure can provide information about a long-term condition in an aquatic organism. The study was conducted to assess genetic diversity and population structure of rabbitfish (Siganus canaliculatus) across an environmental gradient in Jakarta Bay and Seribu Islands. A total of 31 individuals were collected using gillnet in study sites. A molecular marker mitochondrial Cytochrome oxidase 1 (CO1) was used to amplify DNA. The result of the phylogenetic tree formed two major clades, which generally separate northern and southern region of Seribu Islands populations. AMOVA analysis showed significant genetic differentiation between the population of Siganus canaliculatus in the north zone (National Park) and south zone Seribu Island $\left(F_{\mathrm{ST}}=0.38, \mathrm{p}<0.005\right)$. The highest haplotype diversity $(H d)$ of Siganus canaliculatus contained was observed in the north (Pulau Semak Daun) and south (Pulau Damar) in both as moderate (0.50). Nucleotide diversity (œÄ) of Siganus canaliculatus was categorized as low (0.076) to moderate (0.500). Environment and humans seem to affect the value of genetic diversity, and as the study suggests, a significant population subdivision makes this population vulnerable.
\end{abstract}

Keywords: Coral triangle, genetic seascape, urban reefs, small scale fisheries

\section{INTRODUCTION}

The rabbitfish (locally known as Baronang) is a group of marine fish that belong to family Siganidae, which usually grouped when they are feeding and very easy to find in seagrass (Madduppa 2014). Rabbitfish is herbivores, they are feeding on seagrass and associated with epiphytic seagrass (Latuconsina et al. 2012;) and macroalgae (Fox and Bellwood 2008; Fox and Bellwood 2008; Fox et al. 2009). This fish also are known as phytoplankton eaters and eat artificial plants (Paruntu 2015) also other artificial feed (Tacon et al. 1990; Laining et al. 2017). Marine fish such rabbitfish become valuable commodity due to their protein source for million people worldwide and source of livelihood (Jennings and Polunin, 1996; Allison and Ellis 2001; Badjeck et al. 2010). The rabbitfish is a popular as good seafood, tasteful, and wellliked, lead them as an important economic value for local fishers (Paruntu 2015). They have been consumed by local people or traded in the fish market. The high demand for this fish can lead to disruption of fish stocks in nature, especially in Seribu Islands region and some area in
Arabian Gulf (Grandcourt et al. 2007). The decrease of the population could lead to an increase in genetic shifting and subside of allele (Garza and Williamson 2001). In addition, populations can turn into homozygotes due to high heterozygosity and reduced alleles. (Lande 1988; Frankham 2005; Willi et al. 2006 ). genetic diversity and a decrease in heterozygosity can be seen in the bottlenecked population (Nei et al. 1975, England et al. 2003). Gene variations within a species both among populations separated geographically and among individuals in a population are the understanding of genetic diversity. Genetic diversity can occur because of changes in constituent nucleotides of DNA (deoxyribonucleic acid). The amount of genetic diversity in the population is determined by many genes that have more than one allele (gene polymorphism), and the number of alleles at each of these genes.

The Kepulauan Seribu is located north of Indonesia's capital city, Jakarta which consists of 110 where Jakarta is occupied by around 10 million residents (Brinkhoff 2011), represent effective to assess impact on coral reef ecosystems (Baum et al. 2015; Damar et al. 2019). National 
Park of Seribu Islands located in the north of Jakarta Bay, administratively included in the village of Panggang Island and Kelapa Island (Fahlevy et al. 2019). The management of the islands surrounding into divided zone waters has 9 Islands (4410.8 ha), protected zone 15 islands (13798,84 ha), intensive use zone 28 islands (12913.84 ha) and traditional use zone 26 islands (75669.26 ha) (TN Laut Kepulauan Seribu 1999).

Effect of overexploitation and habitat degradation can cause a reduction in genetic diversity (Toro et al. 2005, Markert et al. 2010, Martinez et al. 2018), which can also occur in remote locations where threats are not controlled. Genetic diversity can also provide useful information about a long-term condition in Inroads aquatic organisms. However, there is no information about this so important in this study to determine the genetic diversity of this species. Therefore this study was conducted to assess genetic diversity and population structure of rabbitfish (Siganus canaliculatus) across an environmental gradient in Jakarta Bay and Seribu Islands.

\section{MATERIALS AND METHODS}

\section{Sample collection}

A total of 31 individuals from 7 localities throughout the Seribu Islands were collected using gillnet in coral reefs and seagrass habitats during several expeditions between September and October 2015 (Figure 1). Caudal fins tissue were collected and preserved in $95 \%$ ethanol for subsequent analysis.

\section{DNA extraction, amplification, and sequencing}

Genomic DNA from each sample was extracted using an extraction kit $\left(\mathrm{gSYNC} \mathrm{CM}^{\mathrm{TM}}\right.$ DNA Extraction Kits GENEAID). A fragment of mitochondrial Cytochrome Oxidase subunit-I gene (COI) was amplified using the following primer set: CO1-510 (Forward) CAT GAA ACC TCC YGC TAT YTCC and CO1-1286 (Reverse): TGT TGT GGG AAG AAA GTY AGR TT (Gotanco et al. 2010).

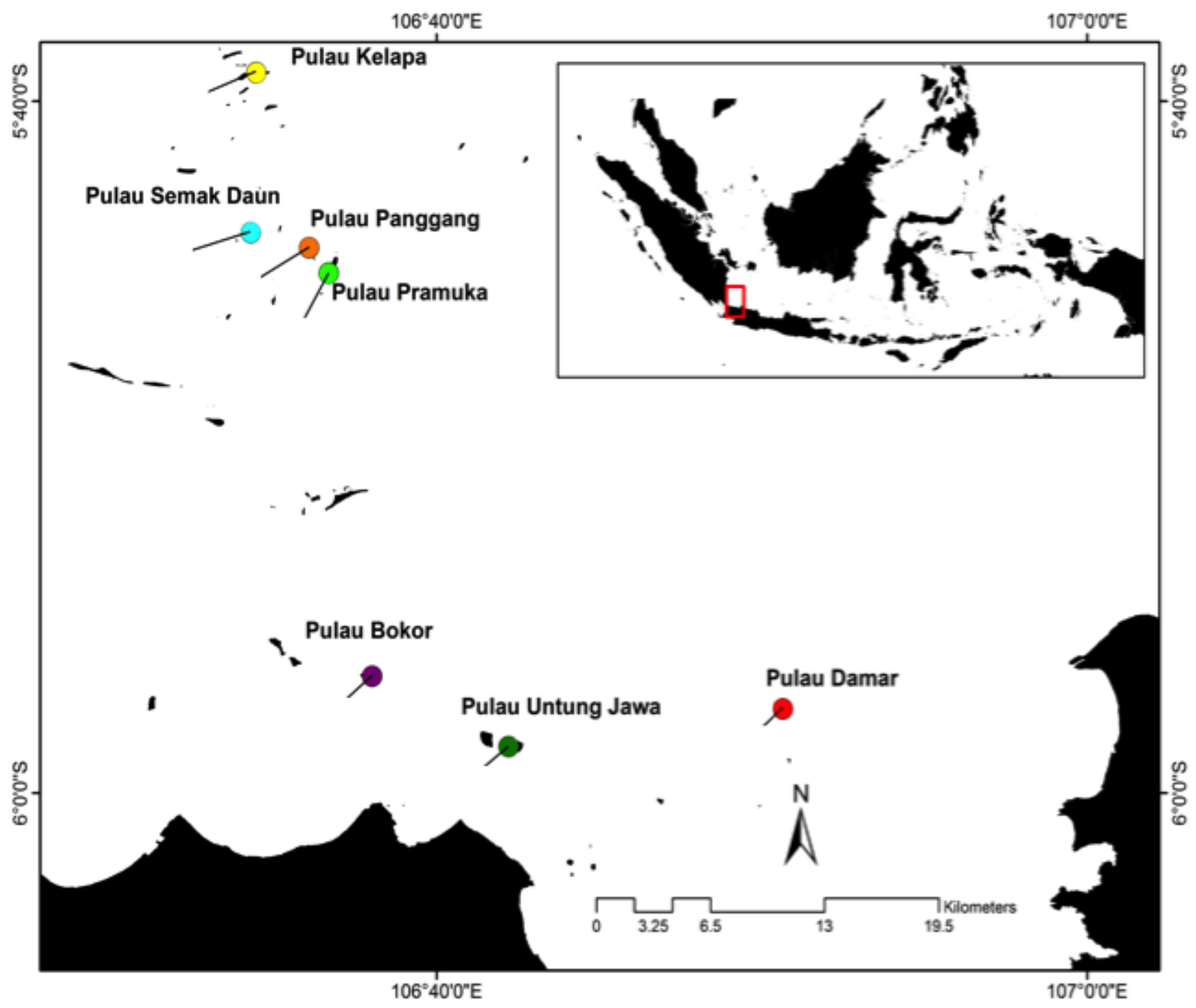

Figure1. The localities (circles) of samples of Siganus canaliculatus used for the analyses of population structure in Seribu Islands, Jakarta Bay, Indonesia in this study 
Polymerase Chain Reaction (PCR) was conducted in 26 $\mu \mathrm{L}$ reaction volume containing one $\mu \mathrm{L}$ template DNA, 12.5 $\mu \mathrm{L}$ of Kapa Mastermix, ten $\mu \mathrm{L}$ ddH2O, $1.25 \mu \mathrm{L}$ of each primer. PCR conditions were: initial denaturation at $94^{\circ} \mathrm{C}$ for $3 \mathrm{~m}$, followed by 40 cycles of denaturation at $94^{\circ} \mathrm{C}$ for $30 \mathrm{~s}$, annealing at $58^{\circ} \mathrm{C}$ for $30 \mathrm{~s}$, and extension at $7^{\circ} \mathrm{C}$ for 2 $\mathrm{m}$. The final extension step was conducted at $72^{\circ} \mathrm{C}$ for 5 min. The quality of PCR products was assessed by agarose gel electrophoresis and ethidium bromide staining and visualized using UV transilluminator. All good PCR products were sent to $1^{\text {st }}$ Base, Malaysia.

\section{Data analysis}

Sequences were aligned and edited in Mega 6.06 (Tamura et al. 2013). Genetic diversity using haplotype diversity $(\mathrm{Hd})$ and nucleotide diversity $(\pi)$. DnaSP 5 (Rozaz et al.. 2003) was used to analyze a number of the haplotype diversity (Hd) (Nei, 1987) and nucleotide diversity $(\pi)$ (Lynch and Creasef 1990). A NeighbourJoining (NJ) tree was constructed in Mega 6 (Tamura et al. 2013) based on Kimura 2-parameter model, and 1000 bootstrap replicates. Epinephelus malabaricus was utilized as an outgroup in phylogenetic reconstruction. Genetic distance (D) was calculated within and between populations. Dendrogram was reconstructed using Minitab 14. Using Arlequin 3.5 (Excoffier and Lischer 2009) was used to investigating the phylogenetic relationship among haplotype using AMOVA (Analysis Molecular Variance).

\section{RESULTS AND DISCUSSION}

\section{Genetic diversity}

The genetic diversity of each population showed that haplotype diversity is quite varied, ranging from 0.07 to 0.50. Haplotype diversity of the lowest on the Pangang Island and Untung Jawa Island, while the highest was in Pramuka Island and Damar Island at 0: 50. The high genetic diversity can be caused populations that are large so allow random mating between individuals. From the results obtained in Table 1 of genetic diversity included in the low category with a value of 0.076 to 0.500 medium category. Values obtained genetic diversity can be affected by some individuals who obtained at each location. The more the number of individuals who observed it will represent the diversity of a population and will affect the value of genetic diversity within the population. Low genetic diversity enables individuals susceptible to disease or environmental change ( Blomqvist et al. 2010, Agha et al. 2018). Unlike the case with high genetic diversity can produce many offspring characteristics of the individual.

Nucleotide diversity (œÄ) ranged between 0.010 and 0.104 . Lowest nucleotide diversity in the population was in Semak Daun Island, and the highest was in Panggang Island. The overall value of 0: 50 haplotype diversity and nucleotide diversity at 0.10 . High genetic diversity enables an organism to survive any changes in the environment (Freeland et al. 2011). The more diverse types of composite haplotype genetic population level of genetic diversity in a population will be higher and vice versa (Smith et al.
1981). Nucleotide diversity (œё) is accurate parameters to describe genetic diversity. Positive elements using nucleotide diversity does not depend on the sample size and the length of DNA (Nei 1987). The genetic diversity of the lowest in Untung Jawa Island and Panggang Island. According to Athena and Inswiasri (2009) Untung Jawa Island waters polluted due to the influence of the island's proximity to the Gulf of Jakarta, this is evidenced by the value of genetic diversity in Untung Jawa Island by 0076. While Panggang Island has low values may be due to the influence of human activity on the island including the island which has a population that is fairly dense (Faiqoh et al. 2015; Fahlevy et al. 2017; Fahlevy et al. 2019).

\section{Population genetic structure}

In Figure 2 showed two major clades. Large clade 2 (green) comes from the southern zone in the Seribu Islands (Damar Island, Bokor Island, Untung Jawa Island). In clade one shows the results of several individuals from the southern zone are in the clade. For example, the island of ITK_P.Untung_Jawa_173 with ITK_P.Untung_Jawa_158. This can occur because of the influence of the individual fish have different reactions to the environment. Reconstruction of phylogenetic trees is a diagram to show the relationships among species based on similarities and differences in their physical characteristics or their genetics. In Figure 1, there are two major clades, in the first major clade clade-clade are small. This may indicate a difference in the nucleotide composition and genetic distance between populations. Between the two major clades, clade one and clade two have a genetic distance of 0.049 , which means there are 49 different base pairs than 1000 base pairs. Both of these resulting in the two major clades in the phylogenetic tree. Saleky et al. (2016) say that the individual is in the same population but showed differences in nucleotide composition high enough it can be due to the effect of migration.

Differences in the composition of the nucleotide bases between individuals can show genetic differences. The difference could be due to the influence of different populations. According to Freeland et al. (2011), different populations indicate a possibility of different habitats as well as their genetic differences. Habitat conditions can affect an individual's genetic material within a species. Genetic differences between populations are usually influenced by several factors such as gene flow and natural selection.

Table 1 Genetic diversity shown by Haplotype diversity $(H d)$ and nucleotide diversity (œÄ) with their number $(\mathrm{N})$ at each sampling site

\begin{tabular}{llll}
\hline Sampling site & $\boldsymbol{N}$ & $\boldsymbol{H} \boldsymbol{d}$ & œ \\
\hline Damar & 2 & 0.500 & 0.028 \\
Bokor & 5 & 0.126 & 0.046 \\
Untung Jawa & 7 & 0.076 & 0.068 \\
Semak Daun & 2 & 0.500 & 0.010 \\
Pramuka & 4 & 0.176 & 0.019 \\
Panggang & 7 & 0.076 & 0.104 \\
Kelapa & 4 & 0.176 & 0.067 \\
\hline
\end{tabular}




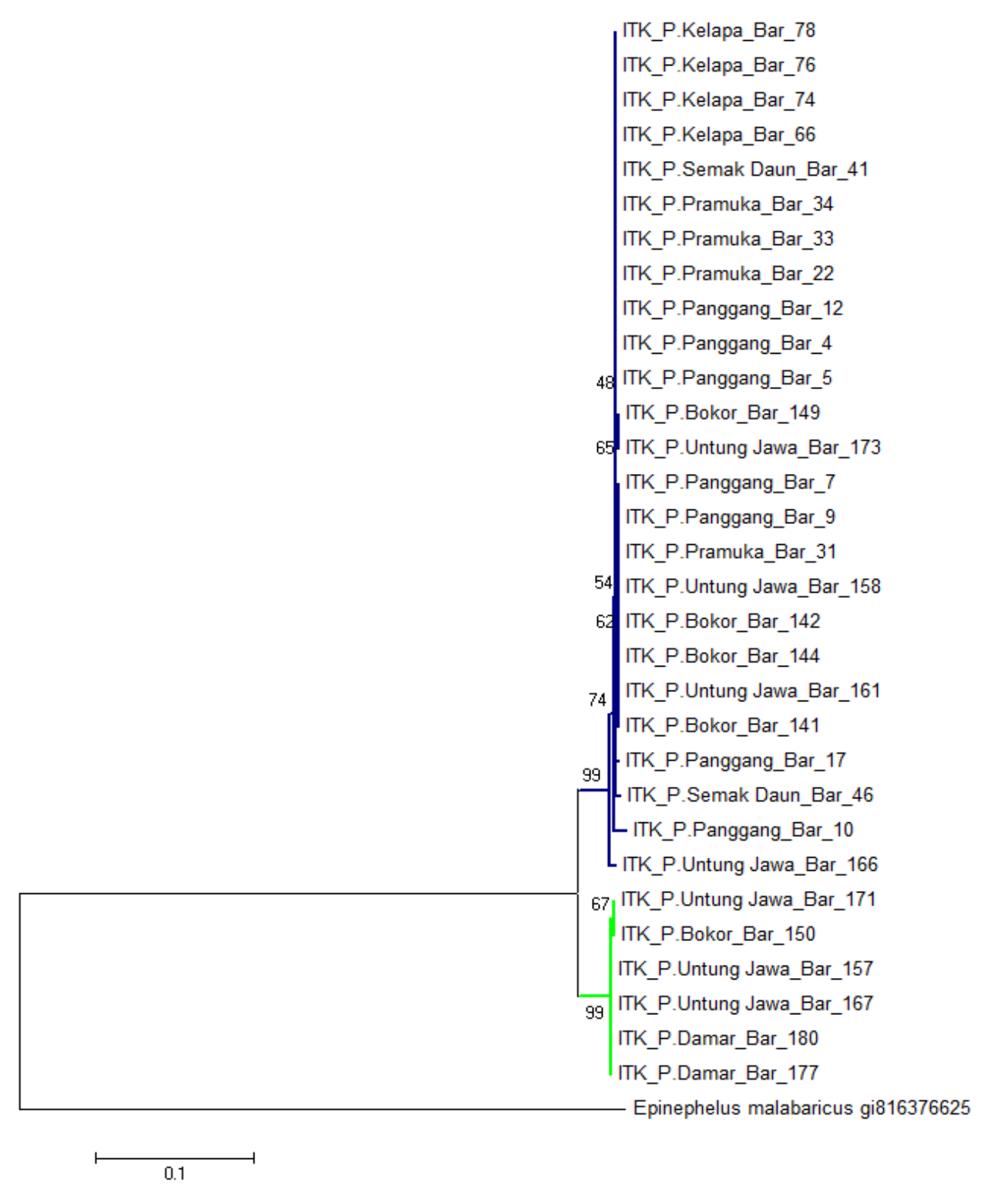

Figure 2 A Neighbour-Joining (NJ) phylogenetic tree reconstruction using 31 sequences of Siganus canaliculatus based on Kimura 2parameter model and 1000 bootstrap replicates

The population Siganus canaliculatus on national park status zones (north) and south of Seribu Islands was significantly different, revealed by AMOVA analysis $\left(F_{\mathrm{ST}}\right.$ $=0.38, \mathrm{p}<0.05)$ (Table 2). Gene flow associated with geographic isolation is affected by the geographical distance and the complexity of biodiversity ( $\mathrm{Wu}$ et al. 2015). According to Mulyasari et al. (2010), population with a low level of differentiation that can be caused because of the many similarities between populations genetic element. The results obtained prove that among the population do not have so much in common genetic elements, and therefore make them vulnerable.
Tabel 2. Genetic differentiation $\left(F_{\mathrm{ST}}\right)$ between and among populations revealed by AMOVA

\begin{tabular}{lllll}
\hline Sources of variation & d.f. & $\begin{array}{c}\text { Variation } \\
(\boldsymbol{\%})\end{array}$ & $\boldsymbol{F}_{\text {ST }}$ & p-value \\
\hline Between populations & 1 & 37.96 & 0.379 & $<0.05$ \\
Among Populations & 29 & 62.04 & & \\
Total & 30 & & & \\
\hline
\end{tabular}




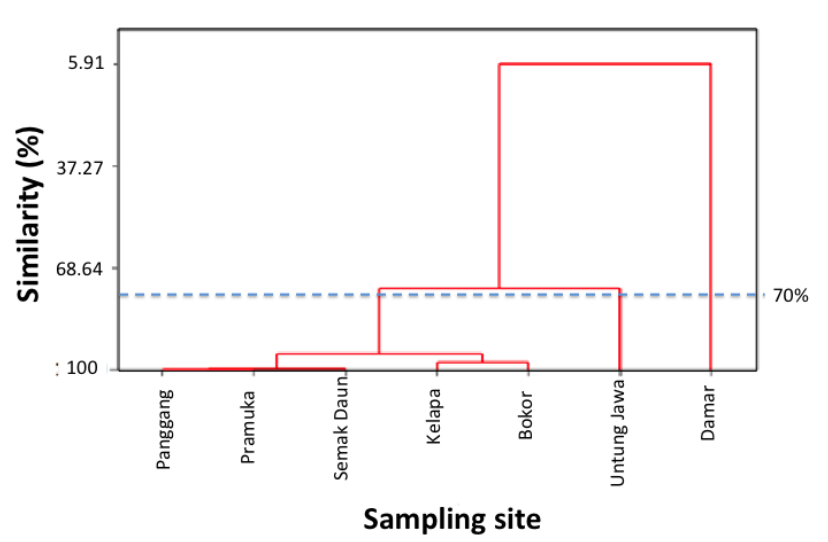

Figure 3 Dendrogram genetic distance matrix showing percentage similarity Siganus canaliculatus between populations with a cut-off $70 \%$ forming three main groups

The lowest genetic distance between populations was observed Pramuka Island and Semak Daun Island, and between Pramuka Island and Panggang Island, in a value 0.007 which mean at 1000 base pairs of nucleotides contained seven different nucleotide base pairs. These sites are close to each other. While the highest genetic distance was 0.062 between Kelapa Island (north) and Damar Island (south), meaning there are 62 different pairs of nucleotides at 1000 nucleotide base pairs. The highest value obtained may be affected because of the location of Damar that is far enough apart to Kelapa Island. The genetic distance shows there is a genetic relationship between populations. The lower the value of genetic distance indicates a very close relationship, and similarity to a target gene $\mathrm{CO} 1$ has a value closer genetic distance between species (Jefri et al. 2015). The higher the value obtained, the more genetic relationship distance between individuals (Akbar et al. 2014; Toha et al. 2016). The genetic distance which less than 0.2 due to their relationship in a species.

In Figure 3, three groups were formed after cut-off in $>70 \%$ similarity, namely (i) Damar Island, (ii) Untung Jawa Island, (iii) Bokor Island, Kelapa Island, Panggang Island and Pramuka Island. In the third group, there were subgroups of the main group formed namely, Kelapa Island and Bokor Island, and Semak Daun Island, Pramuka Island, and Panggang Island. It can be proved that the genetic relationship between Pramuka Island and Panggang Island has a value of 0.007 at 1000 pairs where there are seven pairs of different (Table 3). Location can affect these values; it can be seen that the Pramuka Island adjacent to Panggang Island, evidenced by the results that the island was included in one group. Unlike the case between Kelapa Island and Bokor Island included in one group, the genetic relationship is quite close to the value of 0.024 ; it can occur due to human factors or relating to such feeding fish (Madduppa et al. 2013; Bramandito et al. 2018). We can see in Kelapa Island, and Bokor Island has a quite low genetic distance (Table 3), this can occur because of individuals of the highly migratory fish which is quite far with the aim to be able to survive. At the farthest genetic distance of Damar Island to Kelapa Island with a value of 0.062 , this can happen because the distance between the
Tabel 3 Genetic distance of Siganus canaliculatus between populations

\begin{tabular}{lcccccc}
\hline & $\begin{array}{c}\text { Untung } \\
\text { Jawa }\end{array}$ & Kelapa & $\begin{array}{c}\text { Semak } \\
\text { Daun }\end{array}$ & Pramuka Panggang Bokor \\
\hline Kelapa & 0.034 & & & & & \\
Semak Daun & 0.029 & 0.012 & & & & \\
Pramuka & 0.029 & 0.008 & 0.007 & & & \\
Panggang & 0.030 & 0.009 & 0.010 & 0.007 & & \\
Bokor & 0.035 & 0.024 & 0.020 & 0.016 & 0.019 & \\
Damar & 0.038 & 0.062 & 0.055 & 0.056 & 0.057 & 0.050 \\
& & & & & & \\
\hline
\end{tabular}

two islands is entirely possible to have a relatively high genetic distance.

In conclusion, the intraspecific genetic diversity and genetic structure between north and south population of study sites differed significantly. This study suggests that environment and humans seem to affect the value of genetic diversity of Siganus canaliculatus in Seribu Islands and Jakarta Bay.

\section{ACKNOWLEDGEMENTS}

This study was carried out and granted within the research scheme of Insentif Riset Nasional (INSINAS) the Indonesian Ministry for Research and Technology (RISTEK) in 2015. We thank the following people and organizations that supported this work: the Seribu Island Marine National Park Officers, Marine Biodiversity and Biosystematics Laboratory of IPB University, Bogor, Indonesia, as well as Marine Science and Technology Diving School, IPB University, Bogor, Indonesia.

\section{REFERENCES}

Agha R, Gross A, Rohrlack T, Wolinska J. 2018. Adaptation of a chytrid parasite to its cyanobacterial host is hampered by host intraspecific diversity. Front Microbiol 9: 921. DOI: 10.3389/fmicb.2018.00921

Akbar N, Zamani NP, Madduppa HH. 2014. Genetic diversity of yellowfin tuna (Thunnus albacares) from two populations in the Moluccas Sea, Indonesia Depik 3 (1): 65-73. [Indonesian]

Amos W, Harwood J. 1998. Factors affecting levels of genetic diversity in natural populations. Phil Trans Biol Sci 353: 177-186.

Athena, Inswiasri. 2009. Public health risk of mercury (Hg)-containing marine products in Seribu Islands, Jakarta. Ekologi Kesehatan 8 (1): 849-859. [Indonesian]

Baum G, Januar HI, Ferse SCA, Kunzmann A. 2015. Local and regional impacts of pollution on coral reefs along the Thousand Islands North of the Megacity Jakarta, Indonesia. PLoS One 10 (9): e0138271. DOI: 10.1371/journal.pone.0138271

Blomqvist D, Pauliny A, Larsson M, Flodin L. 2010. Trapped in the extinction vortex? Strong genetic effects in a declining vertebrate population. BMC Evolutionary Biology 10: 1-9.

Bramandito A, Subhan B, Prartono T, Nurlita NP, Januar HI, Madduppa H.2018. Genetic diversity and population structure of Siganus fuscescens across urban reefs of Seribu Islands, Northern of Jakarta, Indonesia. Biodiversitas 19 (6): 1993-2002 
Brinkhoff T. The principal agglomerations of the world. (2011) Available: http: //www.citypopulation.de. Accessed 14 June 2019.

Damar A, Hesse K, Colijn F, Vitner Y. 2019. The eutrophication status of the Indonesian sea large marine ecosystem: Jakarta Bay, 2001-2013. Deep Sea Res Part II: Top Stud Oceanogr 163: 72-86

Fahlevy K, Khodijah S, Nasrullah IA, Fathihatunnisa R, Subhan B, Madduppa H. 2017. Site and depth influence on coral reef structure and composition in Seribu Islands, Jakarta. Aceh J Ani Sci 2 (1): 28 38 DOI: 10.13170/ajas.2.1.8212

Fahlevy K, Prabowo B, Mubarok MWI, Fahrezi FY, Abdurrahman MI, Prasetia MF, Wicaksono RZ, Aprizan M, Subhan B, Madduppa H. 2019. Comparing hard coral cover between Panggang and Kelapa Island Administrative Village, Seribu Islands National Park, Indonesia. IOP Conf. Ser: Earth Environ Sci 241: 012036. DOI 10.1088/1755-1315/241/1/012036

Faiqoh E, Ayu IP, Subhan B, Syamsuni YF, Anggoro AW, Sembiring A. 2015. Geographical Variation of Zooplankton Abundance Relative to Anthropogenic Pressure in Kepulauan Seribu, Indonesia. J Mar Aquat Sci 1: 19-22.[Indonesian]

Fox RJ, Bellwood DR. 2008. Remote video bioassays reveal the potential feeding impact of the rabbitfish Siganus canaliculatus (f: Siganidae) on an inner-shelf reef of the Great Barrier Reef. Coral Reefs 27: 605615 DOI: $10.1007 / \mathrm{s} 00338-008-0359-6$.

Fox RJ, Bellwood DR. 2013. Niche partitioning of feeding microhabitats produces a unique function for herbivorous rabbitfishes (Perciformes, Siganidae) on coral reefs. Coral Reefs 32: 13-23. DOI: 10.1007/s00338-012-0945-5.

Fox RJ, Sunderland TL, Hoey AS, Bellwood DR. 2009. Estimating ecosystem function: contrasting roles of closely related herbivorous rabbitfishes (Siganidae) on coral reefs. Mar Ecol Prog Ser 385: 261 269. DOI 10.3354/meps08059.

Frankham, R. 2005. Stress and adaptation in conservation genetics. J Evol Biol 18: 750-755.

Freeland JR, Kirk H, Petersen SD. 2011. Molecular Ecology. 2nd ed. Wiley-Blackwell, West Sussex, UK.

Garza JC, Williamson EG. 2001 Detection of reduction in population size using data from microsatellite loci. Mol Ecol 10 (2): 305-318.

Gotanco R G R, Manglicmot M T, and Pante M J R. 2010. Multiplex PCR and RFLP Approaches for identification rabbitfish (Siganus) species using mitochondrial regions. Mol Ecol Resour 10: 741-743.

Grandcourt E, Al-Abdessalam T, Francis F, Al-Shamsi A. 2006 Population biology and assessment of the white-spotted spine foot Siganus canaliculatus (Park, 1797), in the Southern Arabian Gulf. J Appl Ichtyol 23 (1): 53-59.

Grande C, Templado J, Cervera JL, Zardoya R. 2004. Molecular phylogeny of Euthyneura (Mollusca: Gastropoda). Mol Biol Evol 21: 303-313

Jefri E, Zamani NP, Subhan B, Madduppa H. 2015. Molecular phylogeny inferred from mitochondrial DNA of the group Epinephelus spp. in Indonesia collected from local fish market. Biodiversitas 16 (2): 254263

Laining A, Usman, Syah R. 2017. Nutritive value of copra cake meal fermented with Rhizopus spp. and its use as protein source for practical diet for rabbitfish (Siganus javus). J Appl Aquacult 29 (3-4), 307-321.

Lande, R.1988. Genetics and demography in biological conservation. Science 241: 1455-1460.
Latuconsina H, Nessa MN, Ambo-Rappe R. 2012. The Composition of species and structure of seagrass community in Tanjung Tiram Inner Ambon Bay. Jurnal Ilmu dan Teknologi Kelautan Tropis. 4 (1): 35 46. [Indonesian]

Madduppa H, Subhan B, Suparyani E, Siregar AM, Arafat D, Tarigan SA, Alimuddin, Khairudi D, Rahmawati F, Bramandito A. 2013. Dynamics of fish diversity across an environmental gradient in the Seribu Islands reefs off Jakarta. Biodiversitas 14 (1): 17-24.

Madduppa H. 2014. Bioekologi dan Biosistematika Ikan Terumbu. IPB Press, Bogor. [Indonesian]

Markert, JA, Champlin DM, Gutjahr-Gobell, R, Grear, JS, Kuhn A, McGreevy TJ, Nacci DE. (2010). Population genetic diversity and fitness in multiple environments. BMC Evol Biol 10: 205. DOI: 10.1186/1471-2148-10-205.

Martinez AS, Willoughby JR, Christie MR. Genetic diversity in fishes is influenced by habitat type and life-history variation. Ecol Evol. DOI: $10.1002 /$ ece 3.4661

Mulyasari SDT, Kristanto AH, Kusmini II. 2010. Characteristic genetic of six population of nilem carp fish at West Java. Jurnal Riset Akuakultur 5 (2): 175-182. [Indonesian]

Nei M, Maruyama T, Chakraborty R. 1975. The bottleneck effect and genetic variability in populations. Evolution 29: 1-10. DOI: $10.2307 / 2407137$.

Nei M. 1972. Genetic distance between populations. Am Nat 106: 283292.

Nei M. 1987. Molecular evolutionary genetics. Columbia University Press, New York.

Paruntu CP. 2015. Mariculture of grouper fish (Ephinephelus tauvina Forsskal, 1775) and rabbitfish (Siganus canaliculatus Park, 1797) in floating net with polyculture system. Jurnal Budidaya Perairan 3 (1): $1-10$.

Saleky D, Setyobudiandi I, Toha HA, Takdir M, Madduppa H. 2016. Length-weight relationship and population genetics of two marine gastropods species (Turbinidae: Turbo sparverius and Turbo bruneus) in the Bird Seascape Papua, Indonesia. Biodiversitas 17 (1): 208-217.

Smith MH, Chesser RK. 1981. Rationale for conserving genetic variation of fish gen pools. Ecol Bull Stockholm 34: 13-22.

Tacon AGJ, Rausin N, Kadari M, Cornelis P. 1990. The food and feeding of marine finfish in floating net cages at the National Seafarming Development Centre, Lampung, Indonesia: rabbitfish, Siganus canaliculatus (Park). Aquacult Fish Manag 21: 375-390.

Taman Nasional Laut Kepulauan Seribu. 1999. Master plan of Kepulauan Seribu National Park Management. Volume II, Proyek Pengembangan Taman Nasional Laut Kepulauan Seribu, Jakarta. [Indonesian]

Toha AH, Widodo N, Subhan B, Himawan MR, Tania C, Noor BA, Stewart BS, Madduppa HH.2016. Close genetic relatedness of whale sharks, Rhincodon typus in the Indo-Pacific region. AACL Bioflux 9 (3): 458-465

Toro M, Caballero A. 2005. Characterization and conservation of genetic diversity in subdivided populations. Phil Trans R Soc 360: 13671378.

Willi Y, Van Buskirk J and Hoffmann AA. 2006. Limits to the adaptive potential of small populations. Ann Rev Ecol Evol Syst 37: 433-458.

Wu Z, Yu D, Wan Z, Li X, Xu X. 2015 Great influence of geographic isolation on the genetic differentiation of Myriophyllum spicatum under a steep environmental gradient. Sci Rep 5: 15618. DOI: $10.1038 /$ srep 15618 